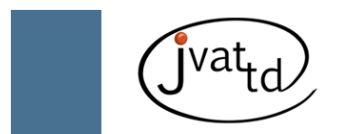

\title{
Assessment of biomedical and pharmacological activities of sea anemones Stichodactyla mertensii and Stichodactyla gigantea from Gulf of Mannar Biosphere Reserve, southeast coast of India
}

Thangaraj S (1), Bragadeeswaran S (1)

(1) Centre of Advanced Study in Marine Biology, Faculty of Marine Sciences, Annamalai University, Parangipettai, Tamil Nadu, India.

\begin{abstract}
Cnidarians comprise an old and diverse animal phylum, and possess a wide variety of biologically active substances. Sea anemones contain a diversity of interesting biologically active compounds including some potent toxins. In the present work, the sea anemones Stichodactyla mertensii and Stichodactyla gigantea, collected from the Mandapam coast, are characterized biomedically and pharmacologically. The crude protein was obtained by using methanol and aqueous extracts. The respective protein contents of $S$. mertensii and S. gigantea were found to be $2.10 \mu \mathrm{g} / \mathrm{mL}$ and $1.87 \mu \mathrm{g} / \mathrm{mL}$. The methanol and aqueous extracts of S. mertensii and S. gigantea yielded six and nine bands by SDS-PAGE on $12 \%$ gel. In the hemolytic assay, both extracts exhibited hemolytic effect on chicken, goat, cow and human erythrocytes (' $\mathrm{A}$ ', ' $\mathrm{B}$ ' and ' $\mathrm{O}$ '). The neurotoxic effects of these crude extracts were determined in vivo using the sea shore crab Ocypode macrocera and mortality was observed. The mouse bioassay for lethality was performed on male albino mice. The crude extract of $S$. mertensii showed higher lethality (58 seconds at $1 \mathrm{~mL}$-dose) than that of $S$. gigantea ( 2 minutes and 10 seconds at $0.75 \mathrm{~mL}$-dose). The analgesic activity test was also carried out on albino mice by Eddy's hot plate and tail-flick methods. The extracts showed moderate analgesic effect by both hot-plate and tail-flick methods. These characteristics emphasize the need for the isolation and molecular characterization of new active toxins in S. mertensii and S. gigantea.
\end{abstract}

Key words: aqueous extract, neurotoxicity, mouse bioassay, analgesic activity.

\section{INTRODUCTION}

The study of marine organisms for their bioactive potential and importance in the marine ecosystem has accelerated in recent years along with the growing recognition of their importance in human life. Sea anemones, like other coelenterates, produce many biologically active polypeptides and proteins, including neurotoxins, pore-forming toxins (or cytolysins), phospholipases and proteinase inhibitors. Anemone neurotoxins (polypeptides with relative low molecular weight (3000 to $5000 \mathrm{kDa}$ ) are very important tools in neurophysiological and pharmacological research $(1,2)$. Nematocysts possess high concentrations of polypeptides and proteins that act as neurotoxins, hemolysins and enzymes, which are responsible for a variety of harmful effects such as cardiotoxicity, dermatitis, local itching, swelling, erythema, paralysis, pain and necrosis (3).

Sea anemones contain a variety of interesting organic compounds including some potent toxins (4). For this reason many investigators have focused attention on the biological activities of the protein molecules of several species of sea anemones. New trends in drug discovery from natural sources have emphasized investigation of the marine ecosystem to explore numerous complex and novel chemical entities. These entities are the source of a new lead for treatment of many diseases such as cancer, AIDS, 
inflammatory condition, arthritis, malaria and a large variety of viral, bacterial and fungal diseases $(5,6)$. A majority of the natural marine products have been isolated from sponges, coelenterates (sea whips, sea anemones, sea pens and soft corals) tunicates, opisthisbranch mollusks, echinoderms, sea grass and bryozoans (5). Therefore, the present study aimed to investigate the biomedical and pharmacological activity of the tropical sea anemones Stichodactyla mertensii and Stichodactyla gigantea from the Mandapam coast of southeast India for their biomedical applications.

\section{MATERIALS AND METHODS}

\section{Sea Anemone}

Specimens of S. mertensii Brandt, 1835 and S. gigantea Forsskal, 1775 were captured at Mandapam (lat. $09^{\circ} 16^{\prime} \mathrm{N}$ and long. $72^{\circ} 12^{\prime} \mathrm{E}$ ), southeast coast of India. They were transported alive in sea water to our laboratory and maintained in the culture tank for extraction.

\section{Animals}

Male albino mice weighing $20 \pm 2 \mathrm{~g}$ were housed under standard laboratory condition. The animals had free access to food and water. All animal bioassays were carried out according to the statement of the Institutional Ethics Committee of Rajah Muthiah Medical College, Annamalai University, Annamalai Nagar, India.

\section{Preparation of the Crude Extracts}

\section{Methanolic extract}

Crude protein was prepared according to the method of Sunahara et al. (7). The sea anemone S. mertensii was fully immersed in methanol and maintained for five days, then the material was removed by squeezing the animal, and the solvent was filtered through Whatman ${ }^{\circledast}$ n. 1 filter paper $(0.4 \mu \mathrm{m})$ (England); it was then evaporated at low pressure using a rotary evaporator (VC 100A, Lark Innovative, India) at $30^{\circ} \mathrm{C}$. The resultant compound was stored at $4^{\circ} \mathrm{C}$ for further screening.

\section{Aqueous extract}

A typical extraction is described below. One frozen specimen of $S$. gigantea was thawed and extracted twice with two volumes of distilled water. The aqueous extract was centrifuged at
$5000 \mathrm{rpm}$ for 15 minutes. The supernatant was collected for lyophilization. The lyophilizing powder was used as a crude toxin and stored at $4^{\circ} \mathrm{C}$ for further use.

\section{Protein estimation}

The protein was determined using the method of Bradford (8) with bovine serum albumin (BSA) as the standard.

\section{SDS-PAGE}

Sodium dodecylsulphate-polyacrylamide gel electrophoresis (SDS-PAGE) was carried out to estimate the molecular weight of the hemolytic toxin according to the method of Laemmli (9). The protein was analyzed by SDS-PAGE, which utilized 5\% stacking gel and 10\% resolving gels. Five molecular weight markers $(20,40,60,80$, and $120 \mathrm{kDa}$ ) were used. Ten microliters of the marker was loaded in the right well as marker and the crude proteins were loaded subsequently wells. Upon completion of electrophoresis, the gel was washed gently with distilled water to remove excess SDS, stained in Coomassie Brilliant Blue R-250 (Coomassie Brilliant Blue R-250, 1.25 g; methanol, $227 \mathrm{~mL}$; glacial acetic acid, $46 \mathrm{~mL}$; distilled water to complete a volume of $500 \mathrm{~mL}$ ) for two hours at room temperature and destained (methanol, $7 \mathrm{~mL}$; glacial acetic acid, $7 \mathrm{~mL}$; and distilled water to reach $100 \mathrm{~mL}$ ) for 48 hours. Protein bands were visualized as dark blue bands on a light blue background. Samples were denatured by boiling in loading buffer containing SDS and $\beta$-mercaptoethanol prior to loading onto the gel. Following electrophoresis at $30 \mathrm{~mA}$ for four hours, gels were stained by Coomassie blue staining.

\section{Hemolytic Study}

\section{Preparation of erythrocyte suspension}

Methanolic and aqueous extracts of the sea anemones S. mertensii and S. gigantea were assayed on chicken, goat, cow and human erythrocytes ('A', 'B' and 'O' blood) according to the method of Pani Prasad and Venkateshvaran (10). The chicken, goat and cow blood were obtained from the nearby slaughterhouse in Parangipettai, while clinically healthy human blood samples were obtained from local hospital using $2.7 \%$ ethylenediaminetetraacetic (EDTA) solution as an anticoagulant at $5 \%$ of the blood 
volume and brought to the laboratory. The blood was centrifuged thrice at 5,000 rpm for five minutes. A $1 \%$ erythrocyte suspension was prepared for hemolysis study.

\section{Hemolytic assay}

The hemolytic assay was performed on a ' $\mathrm{V}$ ' shaped sterile Laxbro microtitre plate (India). Serial two-fold dilutions of the venom extract $(100 \mu \mathrm{L} ; 1 \mathrm{mg}$ crude in $1 \mathrm{~mL}$ PBS) were made in PBS ( $\mathrm{pH}$ 7.2) starting from 1: 2. An equal volume of $1 \%$ human RBC was added to each well. The plate was shaken to mix the RBC and venom extract. The plates were incubated at room temperature for two hours before reading the results. Appropriate control was included in the tests. Erythrocyte suspensions to which distilled water was added $(100 \mu \mathrm{L}$ respectively) served as blanks for negative control. Button formation at the bottom of the wells was taken as negative. The reciprocal of the highest dilution of the venom extracted showing the hemolysis was defined as one hemolytic unit.

\section{Acute Toxicity Test}

\section{Crab toxicity}

The acute toxicity study was performed on the isolated crude extract using adult Ocypode macrocera sea shore crabs $(20 \pm 30 \mathrm{~g}$ total body weight). This assay was carried out by injecting crude extract into the third walking leg of the crab at concentrations of $0.2,0.4,0.6,0.8$ and/ or $1.0 \mathrm{mg} / \mathrm{mL}$ with subsequent symptoms being observed for two hours. Triplicates of each concentration were used. The $\mathrm{LD}_{50}$ was obtained by the Lehman method. The crude extract, which displayed sodium-channel activity, can be already detected by this test. Positive reactions were observed as tetanic concentrations in the extremities of the sea shore crab.

\section{Mice bioassay}

The mice bioassay was carried out according to the method of Gouiffes et al. (11). The lethality bioassay was done by using healthy male albino mice $20 \pm 2 \mathrm{~g}$ that were maintained in a healthy condition in the laboratory. Mice in triplicate sets were challenged intraperitoneally with $0.25,0.50$, 0.75 and $1.0 \mathrm{~mL}$ of the crude toxin, dissolved at $5 \mathrm{mg} / \mathrm{mL}$. A control was maintained in each case by injecting an equal volume of PBS ( $\mathrm{pH}$ 7.4).
The times of injection and death, in addition to behavioral changes before death, were recorded.

\section{Evaluation of analgesic activity}

\section{Tail-flick method}

The central analgesic activity was tested by the tail-flick method in male albino mice as described by D'Amour and Smith (12). Healthy male albino mice weighing $5 \mathrm{mg} / \mathrm{kg}$ having fasted overnight were divided into eight groups with six animals in each group. The crude extracts were dissolved in PBS solution and administered intramuscularly into the root of the tail at $100 \mu \mathrm{L} /$ mouse. Control mice were maintained without administration of any toxin. For this tail-flick test, the mice were retrained in a soft tissue pocket and the distal half of the tail was immersed in water heated up to $50^{\circ} \mathrm{C}$. Latency for tail-flick was measured with a 10-second cutoff time to avoid animal injury. Tail withdrawal from the heat (flicking response) was taken as the endpoint. The tail flick latencies were recorded pre-drug and then at 15,30, 60, 90 and 120 min after administration of drugs.

\section{Hot-plate test}

The hot-plate was used to measure response latencies according to the method described by Eddy and Leimbach (13). The paws of mice are very sensitive to heat even at temperatures not damaging the skin. The response is in the form of jumping, paw withdrawal or licking of the paws. The animals were placed on Eddy's hot plate kept at a temperature of $55 \pm 0.5^{\circ} \mathrm{C}$. A cut off period of 15 seconds was observed to avoid damage of the paw. Reaction times and the type of response were noted using a stopwatch. The latency was recorded before and at 15, 30, 60 and 120 minutes after both test and standard.

\section{Central Nervous System Depressant Activity}

The CNS depressant activity was measured according to the method of Kulkarni and Dandiya (14) using an actophotometer (Medicraft, model n. 600 M-6 D, serial n. PA-0135). Male albino mice $(20 \pm 2 \mathrm{~g})$ were housed under a 12:12 hour dark-light cycle. The extract concentrations were $2 \mathrm{mg} / \mathrm{kg}$ of body weight. A mouse without administration of any toxin or known painkiller was used as control while those injected intraperitonealy (IP) with paracetamaol (Crocin ${ }^{\circledR}$ at $0.25 \mathrm{~mL}$ ) served as reference standard. The 
basal reaction times and administrations of crude extract after 15, 30, 45, 60, 120 minutes were noted and percentage decrease of motor activity represented.

\section{Anti-Inflammatory Activity}

Anti-inflammatory activity was measured according to Smith (15). A group of two mice in each case was injected subplantarly with 0.1 $\mu \mathrm{L}$ of the crude toxin in the right footpad and with $0.1 \mathrm{~mL}$ of buffered saline in the left footpad. Two hours after injection, percentage of size increase was measured and the growth of the envenomoted paw relative to the saline-injected paw was defined as the edema ratio (ER). The minimum edematous dose was defined as the dose causing $105 \%$ ER.

\section{RESULTS}

\section{Extraction}

The aqueous extract of the sea anemone $S$. mertensii was filtered through Whatman n.1 filter paper and was then transformed into a lyophilized powder form by using a lyophilizer (Penquin Classic plug $4 \mathrm{~kg}$, freeze dryer, Lark Innovative). The methanol extract of the sea anemone S. gigantea was concentrated under reduced pressure in a rota evaporator (model Lark Innovative, VC 100A). Finally, these crude extracts were stored for further studies.

\section{Protein Content of the Crude Extracts}

The respective protein contents in S. mertensii and $S$. gigantea were found to be $2.10 \mu \mathrm{g} / \mathrm{g}$ and $1.87 \mu \mathrm{g} / \mathrm{g}$.

\section{Molecular Weight Determination-SDS-PAGE}

Utilizing SDS-PAGE on $12 \%$ gel, crude protein of $S$. mertensii yielded four bands ranging from 45 to $65 \mathrm{kDa}$ with well-defined bands at $45 \mathrm{kDa}$, $58 \mathrm{kDa}, 61 \mathrm{kDa}, 65 \mathrm{kDa}$, whereas S. gigantea contained seven bands ranging from 42 to $95 \mathrm{kDa}$ ranging from $42,65,70,75,78,85$ and $95 \mathrm{kDa}$ (Figure 1) respectively. From the above results, it is clearly indicated that these two samples of sea anemones possess some protein bands in common.

\section{Hemolytic Assay}

The features of hemolysis were present in the crude extracts of S. mertensii and S. gigantea,

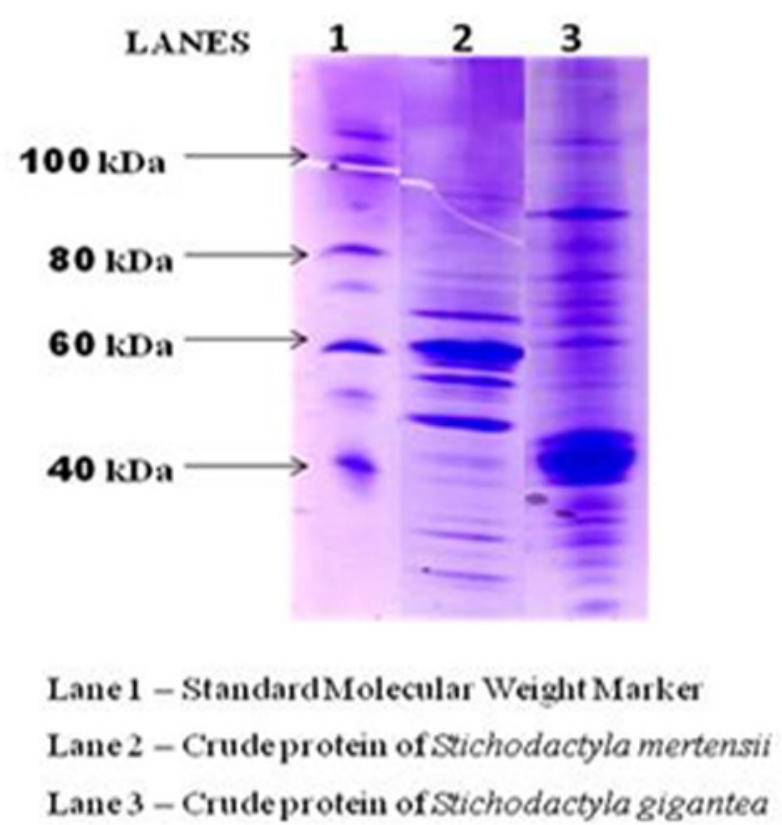

Figure 1. SDS-PAGE analysis of crude venom from $S$. gigantea and S. mertensii.

but activities differed slightly depending on the type of blood (Figure 2). The chicken, goat, cow and human blood groups, including erythrocyte types 'B' and 'O', were vulnerable to lysis provoked by either $S$. mertensii or $S$. gigantea extracts. The crude protein of $S$. mertensii extract showed a maximum of $32 \mathrm{HU}$ in chicken blood and a minimum of $4 \mathrm{HU}$ in cow blood. S. gigantea presented a peak of $16 \mathrm{HU}$ in chicken, goat and human 'B' and 'O' blood groups and a minimum of $8 \mathrm{HU}$ in cow blood.

\section{Crab Toxicity Assay}

The results showed that the crude extract of both species $S$. mertensii and S. gigantea evidenced biological activity on crab $O$. macrocera at the doses of $0.2,0.4,0.6,0.8$ and $1.0 \mathrm{mg} / \mathrm{mL}$. After injection of crude extracts $(1 \mathrm{mg} / \mathrm{mL})$ into their third walking legs, strong contraction of the walking appendages was observed followed by intense spasmodic movement. The legs became tremulous with involuntary lateral movement; appendages shivered and presented stiffness; the carapace changed color; and there was complete loss of control and paralysis. In the case of $S$. mertensii mortality was observed within 30 seconds at the dose of $1.0 \mathrm{mg} / \mathrm{mL}$; the crabs had died within four minutes. S. gigantea crude toxin injections with $0.8 \mathrm{mg} / \mathrm{mL}$ produced crab fatality 


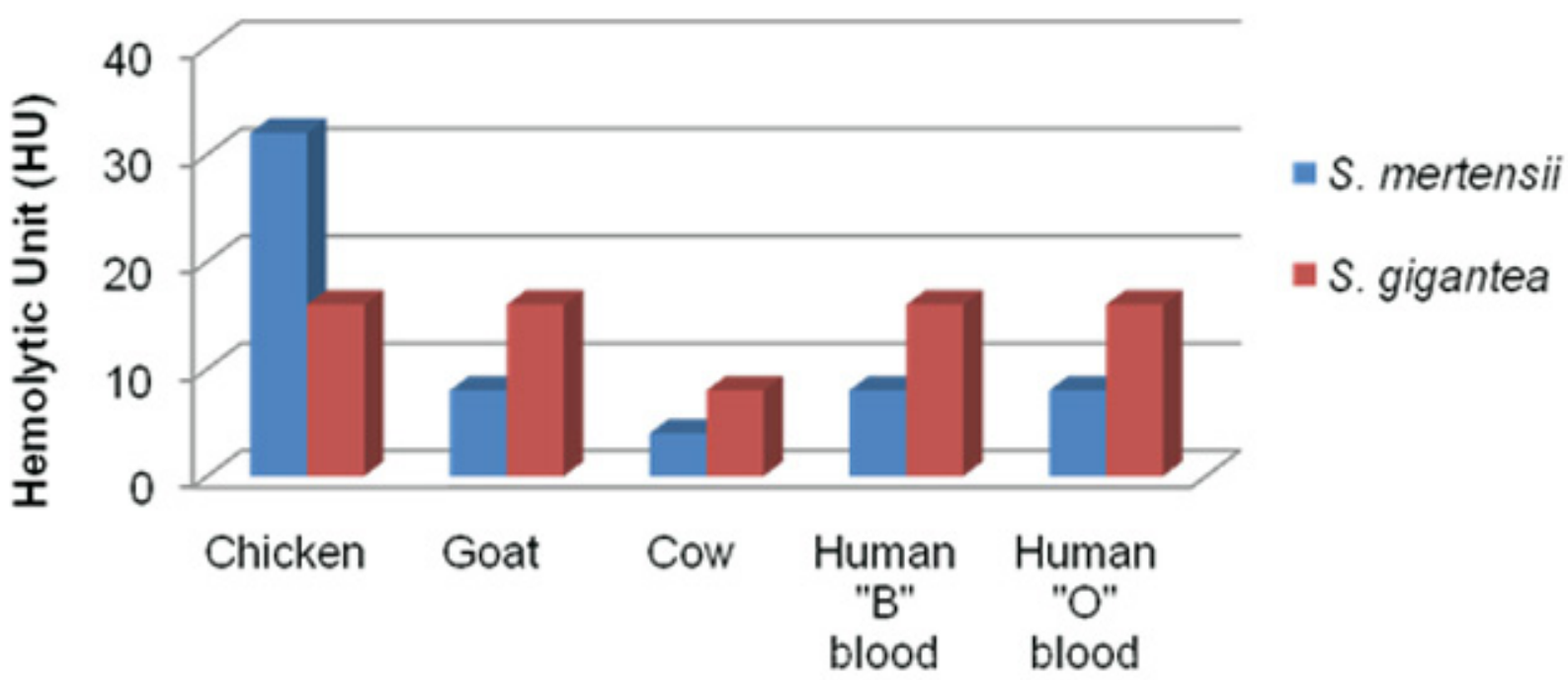

Sample Tested

Figure 2. Hemolytic activity of the sea anemones S. mertensii and S. gigantea.

at 6 minutes and 48 seconds, and at $1.0 \mathrm{mg} / \mathrm{mL}$ crab death occurred within 5 minutes and 20 seconds, respectively. No lethality was observed from the doses $0.2 \mathrm{mg} / \mathrm{mL}$ and $0.4 \mathrm{mg} / \mathrm{mL}$. Across the dose range from 0.2 to $1.0 \mathrm{mg} / \mathrm{mL}$ all crabs showed spasmodic movement.

\section{Mice Bioassay for Lethality}

Crude protein of $S$. mertensii and S. gigantea, when injected IP into male albino mice $(20 \pm 2 \mathrm{~g})$ at doses of $0.25,0.50,0.75$, and $1.0 \mathrm{~mL}$, showed toxicity symptoms and mortality. In the case of $S$. mertensii lethality was observed at the dose of 1.0 $\mathrm{mL}$ with a death time of 58 seconds. The crude extract of $S$. gigantea showed lethality at a dose of $0.75 \mathrm{~mL}$ in 2 minutes and 10 seconds (Table 1 ).

\section{Analgesic Activity}

\section{Tail-flick method}

Employing the tail-flick method, the maximum analgesic ratio (AR) was found to be 10 in the crude extract of $S$. mertensii and a $5 \mathrm{AR}$ minimum was noted after 15 minutes. In the case

Table 1. Mouse toxicity of sea anemones S. mertensii and S. gigantea samples at $5.0 \mathrm{mg} / \mathrm{mL}$ intraperitoneally injected into male albino mice $(20 \pm 2 \mathrm{~g})$

\begin{tabular}{c|c|c|l}
\hline $\begin{array}{c}\text { Sample } \\
\text { number }\end{array}$ & \multirow{2}{*}{ Extracts } & $\begin{array}{c}\text { Injected } \\
\text { volume }(\mathrm{mL})\end{array}$ & \multicolumn{1}{c}{ Symptoms } \\
\hline \multirow{2}{*}{1} & \multirow{3}{*}{ S. mertensii } & 0.25 & $\begin{array}{l}\text { Widespread fore limbs, prolonged palpitation, closed eyes, } \\
\text { grooming, shivering of fore limbs - not lethal }\end{array}$ \\
\cline { 3 - 4 } & & 0.50 & Foaming from mouth, tonic convulsions - not lethal \\
\cline { 3 - 4 } & & 0.75 & Rolling of tail, paralysis - not lethal \\
\cline { 3 - 4 } & \multirow{3}{*}{2} & 1.00 & Palpitation, urination, suddenly death - lethal \\
\hline \multirow{2}{*}{ S. gigantea } & 0.25 & $\begin{array}{l}\text { Widespread fore limbs, prolonged palpitation, grooming, } \\
\text { shivering of fore limbs - not lethal }\end{array}$ \\
\cline { 3 - 4 } & & 0.50 & Escape reaction, tonic convulsions - not lethal \\
\cline { 3 - 4 } & & 0.75 & Excess defection, dragging of hind limbs, paralysis - lethal \\
\hline & & 1.00 & Urination, Paralysis and coma - lethal \\
\hline
\end{tabular}




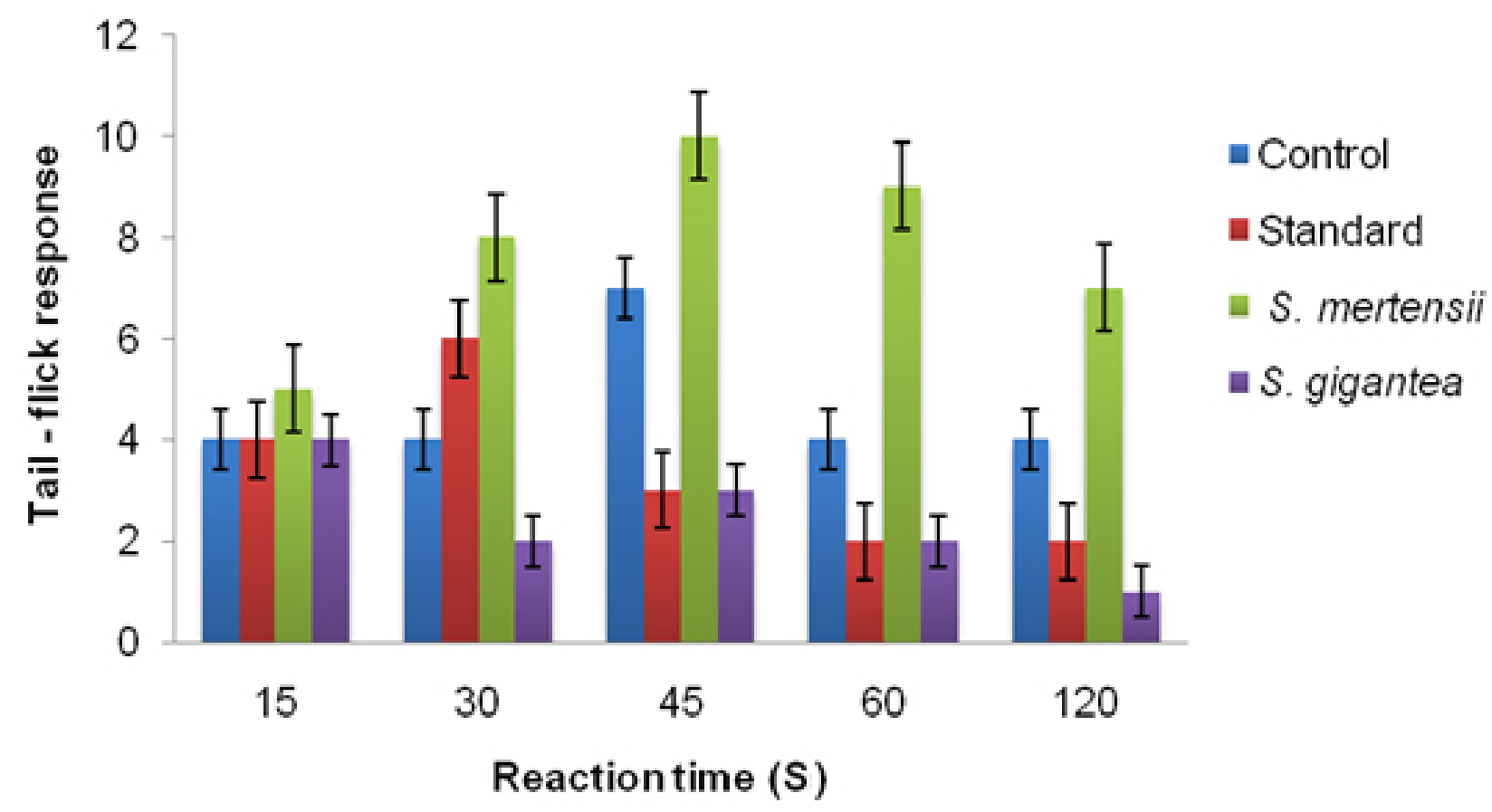

Figure 3. Analgesic activities by tail-flick response of male albino mice to $S$. mertensii and S. gigantea extract at $2 \mathrm{mg} \cdot \mathrm{kg}^{-1}$ of $20 \pm 2 \mathrm{~g}$.
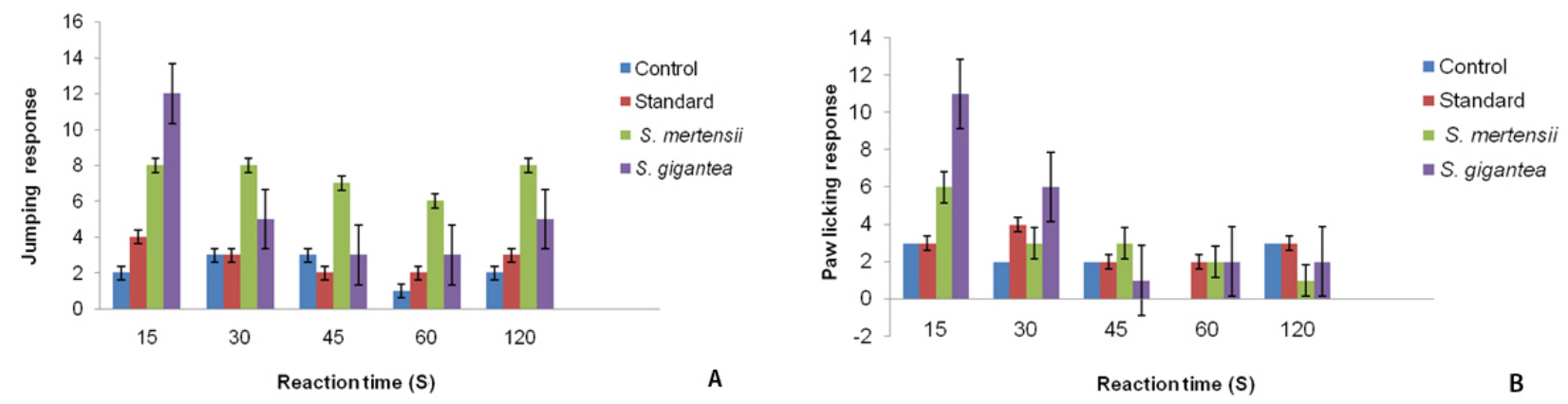

Figure 4. Analgesic activities of $20 \pm 2 \mathrm{~g}$ male albino mice produced by S. mertensii and S. gigantea extract at $2 \mathrm{mg} \cdot \mathrm{kg}^{-1}$ under the hot plate method.

of S. gigantea the maximum analgesic ratio was 4 AR after 15 minutes and minimum 1 AR after 120 minutes (Figure 3).

\section{Hot-plate method}

In the hot-plate method, the analgesic ratio (AR) was determined by registering paw licking and jumping response of mice after drug administration. The paw licking peaked at 6 AR 15 minutes after $S$. mertensii extract administration, whereas the $S$. gigantea showed a maximum of 11 AR after 15 minutes. The jumping response presented an $8 \mathrm{AR}$ maximum in $S$. mertensii at $15,30,120$ minutes and minimum of $6 \mathrm{AR}$ at 60 minutes, while $S$. gigantea peaked at $12 \mathrm{AR}$ in 15 minutes and reached its minimum of $3 \mathrm{AR}$ at 45 and 60 minutes (Figure 4).

\section{Central Nervous System Depressant Activity}

Respective maximum decreases of depressant activity of $69.6 \%$ and $35.5 \%$ were recorded in crude extracts of $S$. mertensii and S. gigantea (Table 2). It was clearly shown that the percentage of motor activity has been calculated from the 
Table 2. Central nervous system activity (CNS) of S. mertensii and S. gigantea extract at $2 \mathrm{mg} \cdot \mathrm{kg}^{-1}$ of $20 \pm 2$ g male albino mice

\begin{tabular}{|c|c|c|c|c|c|}
\hline \multirow{2}{*}{$\begin{array}{l}\text { Sample } \\
\text { number }\end{array}$} & \multirow{2}{*}{$\begin{array}{l}\text { Treatment } \\
\left(5 \mathrm{mg}^{\mathrm{kg}} \mathrm{kg}^{-1}\right)\end{array}$} & \multirow{2}{*}{$\begin{array}{l}\text { Body weight } \\
\text { (g) }\end{array}$} & \multicolumn{3}{|c|}{ Locomotor activity (scores) in $10 \mathrm{~min}$} \\
\hline & & & $\begin{array}{c}\text { Before } \\
\text { treatment }\end{array}$ & $\begin{array}{c}\text { After } \\
\text { treatment }\end{array}$ & $\begin{array}{l}\text { \% Decrease of } \\
\text { motor activity }\end{array}$ \\
\hline 1 & Control (saline) & 20.8 & 534 & 485 & 9.1 \\
\hline 2 & $\begin{array}{c}\text { Standard } \\
\text { (paracetamol) }\end{array}$ & 22.02 & 382 & 345 & 9.6 \\
\hline 3 & $\begin{array}{c}\text { Crude extract of } S . \\
\text { mertensii }\end{array}$ & 29.98 & 462 & 140 & 69.6 \\
\hline 4 & $\begin{array}{l}\text { Crude extract of } S . \\
\text { gigantea }\end{array}$ & 27.18 & 414 & 267 & 35.5 \\
\hline
\end{tabular}

Table 3. Anti-inflammatory formation effect of S. mertensii and S. gigantea extract on at $2 \mathrm{mg} \cdot \mathrm{kg}^{-1}$ of $20 \pm 2$ g male albino mice

\begin{tabular}{c|c|c|c}
\hline \multirow{2}{*}{$\begin{array}{c}\text { Sample } \\
\text { number }\end{array}$} & Treatment $\left(\mathbf{5} \mathbf{~ m g . k g} \mathbf{~}^{-1}\right)$ & \multicolumn{2}{|c}{ Paw edema response $(\mathbf{c m})$} \\
\cline { 3 - 4 } & & Before injection & After injection \\
\hline 1 & Control (saline) & 1.2 & 1.3 \\
\hline 2 & Crude extract of S. mertensii & 1.4 & 1.6 \\
\hline 3 & Crude extract of S. gigantea & 1.2 & 1.5 \\
\hline
\end{tabular}

basal score and after ten minutes of injection of crude extract.

\section{Anti-Inflammatory Activity}

The effects obtained by $100 \mathrm{mg} / \mathrm{kg}$ of the aqueous and methanol extracts of $S$. mertensii and $S$. gigantea on mice hind paw edema are shown in Table 3 . The both extracts significantly inhibited the inflammatory action in vivo in male albino mice.

\section{DISCUSSION}

The present investigation found the respective protein contents of $S$. mertensii and S.gigantea extracts to be $2.10 \mu \mathrm{g} / \mathrm{mL}$ and $1.87 \mu \mathrm{g} / \mathrm{mL}$. Previously, Sánchez-Rodríguez and CruzVazquez (16) reported the protein content of the sea anemone L. danae as $0.122 \mathrm{mg}$ in $1 \mathrm{mg}$ of crude extract and also a high protein concentration of $79.6 \mu \mathrm{g} / \mathrm{mg}$ from the box jellyfish Carybdea marsupialis. Adhikari et al. (17) have showed $50-400 \mu \mathrm{g} / \mathrm{mL}$ from the tentacle extract of sea anemone $P$. indicus.
The toxic compounds from sea anemones are proteins whose structural properties are determinable. In the present study, S. mertensii and $S$. gigantea presented three types of neurotoxins with molecular weights between $45 \mathrm{kDa}$ and $95 \mathrm{kDa}$. Subsequent results were from the sea anemone $L$. danae found molecular weights of 62.5 and $58 \mathrm{kDa}(16)$. Uechi et al. (18) isolated $19 \mathrm{kDa}$ proteins from the globular vesicles of the sea anemone A. villosa. Bernheimer and Avigad (19) have isolated $80 \mathrm{kDa}$ protein from sea anemone $M$. senile. Monastyrnaya et al. (20) have isolated $20 \mathrm{kDa}$ protein from the sea anemone $R$. macrodactylus.

Sea anemones contain a variety of bioactive compounds including some toxins that are known to possess potent hemolytic properties (21). In the present research the $S$. mertensii and S. gigantea extracts showed $32,16 \mathrm{HU}$ in chicken blood and 4, $8 \mathrm{HU}$ in cow blood. These hemolytic activities agreed with an earlier report of Vinoth S. Ravindran (22), who reported the hemolytic activity of three anemone species $H$. magnifica, S. haddoni and S. helianthus to be 20, 23 and 25 
HU, respectively, in chicken, goat and human erythrocytes. Similar results have been shown from the sea anemone $B$. annulata in mouse erythrocytes by Santamaría et al. (23). Shiomi et al. (24) found specific hemolytic activities of $106,500 \mathrm{Hu} / \mathrm{mg}$ from the sea anemone $A$. japonica.

The neurotoxicity of the sea anemone toxins to the sea shore crab Ocypode quadrata was documented for the first time by Beress and Zwick (25), who characterized biological activity and physiological effects of neurotoxin on the organism followed by neurotoxic effects, convulsions, paralysis and death. The present study has isolated a neurotoxin that was extremely active in the sea shore crab Ocypode macrocera. From the extract of $S$. mertensii at a dose of 1.0 $\mathrm{mg} / \mathrm{mL}$ mortality was observed 30 seconds and the crabs had died within four minutes, while in the case of $S$. gigantea at $1.0 \mathrm{mg} / \mathrm{mL}$ mortality occurred at 6 minutes and 48 seconds following spasmodic movement, shivering, change in carapace color and paralysis. Similar symptoms were also reported as being caused by whole extracts of two sciaenids $(26,27)$.

The S. mertensii and S. gigantea extracts were found to have both biomedical and pharmacological potential. The analgesic potential of these sea anemone extracts produced good results at all time intervals (15, $30,45,60$ and 120 minutes) in tail-flick and hotplate methods, these finding differ slightly from those of previous studies on analgesic effects of fruit extract of M. parvifolia by Saneja et al. (28). In the previous studies the fruit extract of the plant was found to be highly active in both hot plate and acetic acid-induced writhing methods at the doses of $(100,250$ and $500 \mathrm{mg} / \mathrm{kg})$ on leaf extract. Andreev et al. (29) have studied the analgesic effect from sea anemone Heteractis crispa. Sakthivel (30) has reported extracts of Conus lentiginosus and C. metabilis as possessing 128 times more analgesic effect than paracetamol. Marwick (31) has shown the venom of Conus magnus to have 1000 times more analgesic activity than morphine. Malarvannan (27) has reported that the ootoxins from fish possess analgesic activity and exhibited an analgesic ratio above 1.0. But in the present investigation, the two sea anemone toxins, S. mertensii and S. gigantea have exhibited much higher analgesic ratios (AR) than fish.

\section{ACKNOWLEDGEMENTS}

The authorsthankProf.T. Balasubramanian, Dean, CAS in Marine Biology and the administration of Annamalai University for providing necessary facilities.

\section{COPYRIGHT}

(C) CEVAP 2012

\section{SUBMISSION STATUS}

Received: June 13, 2011.

Accepted: August 19, 2011.

Abstract published online: October 6, 2011.

Full paper published online: February 28, 2012.

\section{CONFLICTS OF INTEREST}

The authors declare no conflicts of interest.

\section{FINANCIAL SOURCE}

The state of Department of Biotechnology and DST-SERC-Fast Tract Project provided the financial grants.

\section{ETHICS COMMITTEE APPROVAL}

The present study was approved by the statement of the Institutional Ethics Committee of Rajah Muthiah Medical College, Annamalai University, Annamalai Nagar, India (registration number 160/1999/CPCSEA/11.01.2008).

\section{CORRESPONDENCE TO}

S. Bragadeeswaran, Centre of Advanced Study in Marine Biology, Parangipettai, 608 502, Tamil Nadu, India. Phone: +91 4144 243223. Mobile: +919894823364. Email: drpragathi@gmail.com.

\section{REFERENCES}

1. Kem WR, Pennington MW, Norton RS. Sea anemone toxins as templates for the design of immunosuppressant drugs. Perspect Drug Discov Des. 1999;15-16:111-29.

2. Rauer $\mathrm{H}$, Pennington M, Cahalan M, Chandy KG. Structural conservation of the pores of calciumactivated and voltage-gated potassium channels determined by a sea anemone toxin. J Biol Chem. 1999;274(31):21885-92.

3. de Oliveira JS, Zaharenko AJ, de Freitas JC, Konno K, de Andrade SA, Portaro FC, et al. Caissarolysin I (Bcs I), a new hemolytic toxin from the Brazilian sea anemone Bunodosoma caissarum: purification and biological characterization. Biochim Biophys Acta. 2006;1760(3):453-61.

4. Beress L. Biologically active compounds from coelenterates. Pure Appl Chem. 1982;54(10):1981-94. 
5. Williams GP, Babu S, Ravikumar S, Kathiresan K, Arul Prathao SA, Chinnapparaj S, et al. Antimicrobial activity of tissue and associated bacteria from benthic sea anemone Stichodactyla haddoni against microbial pathogens. J Environ Biol. 2007;28(4):782-93.

6. Nazar S, Ravikumar S, Williams GP, Syed Ali M, Suganthi P. Screening of Indian coastal plant extracts for larvicidal activity of Culex quinquefaciatus. Ind J Sci Technol. 2009;2(3):24-7.

7. Sunahara S, Muramoto K, Tenma K, Kamiya $\mathrm{H}$. Amino acid sequence of two sea anemone toxins from Anthopleura fuscoviridis. Toxicon. 1987;25(2):211-9.

8. Bradford MM. A rapid and sensitive method for the quantification of microgram quantities of protein using the principle of protein-dye binding. Anal Biochem. 1976;72:248-54.

9. Laemmli UK. Cleavage of structural proteins during the assembly of the head of bacteriophage T4. Nature. 1970;227(5259):680-5.

10. Pani Prasad V, Venkateshwaran K. Microhaemolytic assay, international training manual on advance techniques in marine biotoxinology. India: CIFE; 1997. $41 \mathrm{p}$.

11. Gouiffes D, Juge M, Grimaud N, Welin L, Sauviat MP, Barbin Y, et al. Bistramide A, a new toxin from the Urochordata Lissoclinum bistratum Sluiter: isolation and preliminary characterization. Toxicon. 1988;26(12):1129-36.

12. D'amour FE, Smith DL. A method for determining loss of pain sensation. J Pharmac Exp Ther. 1941; 72(1):74-9.

13. Eddy NB, Leimbach D. Synthetic analgesics. II. Dithienylbutenyl and dithienylbutylamines. J Pharmacol Exp Ther. 1953;107(3):385-93.

14. Kulkarni SK, Dandiya PC. Influence of chemical stimulation of central DA system on the open field behaviour of rats. Pharmakopsychiatr Neuropsychopharmakol. 1975;8(1):45-50.

15. Smith M. Skin problems from marine echinoderms. Dermatol Ther. 2002;15(1): 30-5.

16. Sánchez-Rodríguez J, Cruz-Vazquez K. Isolation and biological characterization of neurotoxic compounds from the sea anemone Lebrunia danae (Duchassaing and Michelotti, 1860). Arch Toxicol. 2006;80(7):43641.

17. Adhikari D, Samanta SK, Dutta A, Roy A, Vedasiromoni JR, Sen T. In vitro hemolysis and lipid peroxidation-inducing activity of the tentacle extract of the sea anemone Paracondylactis indicus in rat erythrocytes. Ind J Pharmacol. 2007;39(3):155-9.

18. Uechi GI, Toma H, Arakawa T, Sato Y. Biochemical and physiological analyses of a hemolytic toxin isolated from a sea anemone Actineria villosa. Toxicon. 2005;45(6):761-766.
19. Bernheimer AW, Avigad LS. A cholesterol-inhibitable cytolytic protein from the sea anemone Metridium senile. Biochim Biophys Acta. 1978;541(1):96-106.

20. Monastyrnaya MM, Zykova TA, Apalikova OV, Shwets TV, Kozlovskaya EP. Biologically active polypeptides from the tropical sea anemone Radianthus macrodactylus. Toxicon. 2002;40(8):1197-217.

21. Karlsson F, Harvey AL, Aneiros A, Castaneda O. Potassium channel toxins from the marine animals. Toxicon. 1993;31:497-540.

22. Vinoth S. Ravindran. Investigation on sea anemones with special reference to biochemical and pharmacological properties and their biomedical application [Ph.D., Thesis]. Parangipettai, India:Centre of Advanced Study in Marine biology, Annamalai University; 2007.

23. Santamaría A, Sánchez-Rodriguez J, Zugasti A, Martínez A, Galán-Arzate S, Segura-Puertas L. A venom extract from the sea anemone Bartholomea annulata produces hemolysis and lipid peroxidation in mouse erythrocytes. Toxicology. 2002;173(3):221-8.

24. Shiomi K., Takamiya M, Yamanaka H, Kikuchi T. Hemolysin isolated from the sea anemone Anthopleura japonica. Toxicon. 1986;26(5):441-1.

25. Beress L, Zwick J. Purification of two crab-paralyzing polypeptides from the sea anemone Bolocera tuediae. Marine Chem. 1980;8:333-8.

26. Muthuramalingam M. Icthyotoxicity of to sciaenids from Bombay waters. M. F. Sc. Dissertation].Mumbai, India: Central Institute of Fisheries Education; 1995.

27. Malarvannan G. Ichthyootoxins from marine carnivorous fishes and their biomedical applications [Ph.D., Thesis]. Parangipettai, India: Centre of Advanced Study in Marine biology, Annamalai University; 2002.

28. Saneja A, Kasuhik D, Khokra SL, Kauuhik P, Sharma C, Aneja KR. Evaluation of activities of Mitragyna parvifolia fruit extract. J Nat Prod. 2009;2:49-54.

29. Andreev YA, Kozlov SA, Koshelev SG, Ivanova EA, Monastyrnaya MM, Kozlovskaya EP, et al. Analgesic compound from sea anemone Heteractis crispa is the first polypeptide inhibitor of vanilloid receptor 1 (TRPV1). J Biol Chem. 2008;283(35):23914-21.

30. Sakthivel A. Biomedicinal activity of conus lentiginosus and Conus mutabilis from Mumbai coast. M. F. Sc [Dissertation]. Mumbai, India: Central Institute of Fisheries Education; 1999.

31. Marwick C. Medical news and perspective. J Am Med Assoc. 1998;279(21):1679-81. 